\title{
We Must Face the Threats
}

\author{
Dario L. Ringach ${ }^{1}$ and J. David Jentsch ${ }^{2}$ \\ ${ }^{1}$ Departments of Neurobiology and Psychology, Jules Stein Eye Institute, David Geffen School of Medicine, and 2Department of Psychology and Psychiatry \\ and Biobehavioral Sciences, University of California, Los Angeles, Los Angeles, California 90095
}

Scientists at the University of California using animals in research have long faced harassment and attacks from animalrights extremists. In the latest wave, which started in 2003, we have seen our cars and homes firebombed or flooded, and we have received letters packed with poisoned razors and death threats via e-mail and voicemail (Miller, 2007; University of California, 2008, 2009; Anti-Defamation League, 2009). Our families and neighbors have been terrorized by angry mobs of masked protesters who throw rocks, break windows, and chant that "you should stop or be stopped" and that they "know where you sleep at night." Some of the attacks have been cataloged as attempted murder. Adding insult to injury, misguided animal-rights militants openly incite others to violence on the Internet, brag about the resulting crimes, and go as far as to call plots for our assassination "morally justifiable." Consequently, animal-rights extremism must be addressed seriously and forcefully; the passage of the Animal Enterprise Terrorism Act in 2006 was one step in this direction, but its constitutionality is now being challenged by animalrights activists who claim that it is overly broad and inhibits constitutionally protected speech (Mintz, 2009). In addition, it is certainly only one mechanism to achieve the relief scientists need to continue their work.

Although animal-rights activists are against all forms of research involving animals, the majority of the recent attacks have concentrated on those using monkeys in their investigations. Obviously, the use of nonhuman primates in research

Received July 31, 2009; accepted Aug. 5, 2009.

Correspondence should be addressed to Dr. Dario Ringach, Departments of Neurobiology and Psychology, Jules Stein Eye Institute, David Geffen School of Medicine, University of California, Los Angeles, Los Angeles, CA 90095. E-mail: dario@ucla.edu.

DOI:10.1523/JNEUROSCI.3738-09.2009

Copyright $\odot 2009$ Society for Neuroscience $\quad$ 0270-6474/09/2911417-02\$15.00/0 presents a unique set of ethical issues because of their complex cognitive and emotional abilities, and accordingly, they represent fewer than $1 \%$ of all the animals used in research. For those researchers studying complex brain functions, including vision, hearing, memory, attention, thinking, and planning, as well as how those processes fail in diseases of the CNS, rodent species simply are not adequate alternatives because of the evolutionary elaboration of these processes in nonhuman and human primates.

Although there has been a focus on primate research, "mainstream" animalrights organizations, such as People for the Ethical Treatment of Animals (PETA) and the Humane Society of the United States, openly oppose all types of animal research, calling it flawed, unnecessary, and unethical. They call it flawed because, in their opinion, results from animal research cannot be translated into treatments for human disease. They call it unethical because, in their view, even if animal research were to be useful, it would be wrong to kill an animal to save human (and animal) lives.

These organizations also mislead the public, suggesting that alternatives to animal research exist or that they could be easily developed, such as the argument that functional magnetic resonance imaging and computer simulations have rendered invasive electrophysiological studies useless. Their message, catered to children in grades kindergarten through 12 (People for the Ethical Treatment of Animals, 2009a) and college students (People for the Ethical Treatment of Animals, 2009b), is finding increased reception as they muddle the discussion with issues regarding the environment (Department of Homeland Security, 2009) and the growing negative social perception of companies involved in pharmaceutical development. "Animal law" programs at various universities are increasingly devel- oping theories of natural rights for nonhuman animals and arguing in favor of providing animals legal standing in our justice system (Wikipedia, 2009). Animalrights philosophers favoring the total abolition of animal use by humans endow their movement with a perceived intellectual standing and a sense of moral superiority (Francione, 2009), one that quickly dissipates when others provide justification for, or (at the least) equivocate on the "morality" of, violent methods to achieve their desired goals (Best, 2009).

The entertainment industry has also contributed to the misperception of science, producing movies that increasingly portray humans and technology as the source of evil, in which mad scientists populate their scripts while animals are often the source of wisdom, kindness, and truth. Some Hollywood celebrities wear AIDS/cancer ribbons one day and participate in PETA fundraising and advertising on another, although research in animals is likely to hold the keys to cures for these conditions. Pseudo-science populates television talk shows, in which some celebrities now advocate for the end to childhood vaccinations.

Regrettably, the attacks and messages from the anti-research lobby have been presented to the public with little opposing force from the scientific community. Traditionally, academic institutions and individual researchers have opted to remain silent about the activities of animalrights extremists and organizations. Such reasoning was based on the fact that, unless the attacks were directed at you or your institution, it would be unwise to draw attention by offering a response. This attitude is no longer tenable. To underscore this point, a recent survey by the Pew Research Center (2009) demonstrated that only $52 \%$ of the public views animal research favorably in the United States. For these reasons, neuroscience re- 
search stands to suffer tremendously if our community does not act in concert immediately.

Time has come for the scientific community to make a concerted effort in condemning animal-rights extremism and in reaching out to the public to explain our work, its importance, and our commitment to the strictest ethical guidelines of animal research. A special effort should be made to emphasize the irreplaceable role for nonhuman primates in neuroscience research to the public. Although scientific societies can play an important role in this respect, such as the many outreach efforts by the Society for Neuroscience, individual investigators cannot delegate their responsibility any longer. We must acknowledge an increasing divide on how animal experimentation is perceived by the broad public. We should open a discourse on the topic, explaining the key role animal research plays in our work and what our society stands to lose if we were to stop it.

Everyone agrees that the welfare of animals and the ethical issues raised by their use in research cannot be taken lightly, but the general public seems to be under the impression that investigators are free to experiment on animals in any way they please. Much needs to be done to explain what exactly goes into conducting animal research: the various settings in which students and trainees are exposed to complex issues of ethics in research, the multiple levels of scrutiny, including review of our grants by the National Institutes of Health, the approval of the research by a university committee (composed of veterinarians and community members), the inspections from federal and state regulators, and accreditation from independent organizations that evaluate the compliance of animal programs. Above all, we should convey to the public our commitment (from students, staff, and faculty) to animal welfare, to refining our procedures, and to reducing the number of animals used in our studies. We should also consider allowing members of the public access to research facilities so that they can observe, firsthand, the measures taken to ensure the well-being of the subjects involved in our scientific enterprise.

We must now face the many threats to animal research in general and to neuroscience in particular. We must prove that "scientific community" means something more than the mere fact that we publish in the same journals and attend the same conferences. We must stand together to defend those colleagues under attack and defend the research we believe to be ethical and critical for our understanding of the brain in health and disease. The public is ready to listen.

\section{References}

Anti-Defamation League (2009) Animal rights extremists target the University of California. http://
www.adl.org/main_Extremism/university_of_ california_animal_rights_extremism.htm.

Best S (2009) http://www.drstevebest.org/.

Department of Homeland Security (2009) Ecoterrorism: environmental and animal-rights militants in the United States. http://www.scribd. com/doc/12251436/DHS-Eco-Terrorism-inUS-2008.

Francione GL (2009) Animal rights: the abolitionist approach. http://www.abolitionistapproach.com/.

Martosko D (2009) Dr. Jerry Vlasak quotes. http:// www.activistcash.com/biography_quotes.cfm/ bid/3437.

Miller G (2007) Science and the public: animal extremists get personal. Science 318:1856-1858.

Mintz H (2009) Federal judge to weigh constitutionality of animal rights anti-terrorism law. http://www. mercurynews.com/crime/ci 12825570.

People for the Ethical Treatment of Animals (2009a) PETA kids on animal testing. http:// www.petakids.com/testing.html.

People for the Ethical Treatment of Animals (2009b) Peta2 site. http://www.peta2.com/.

Pew Research Center (2009) Public praises science; scientists fault public, media. http:// pewresearch.org/pubs/1276/science-survey.

University of California (2008) The Regents of the University of California vs. UCLA Primate Freedom; Animal Liberation Brigade; Animal Liberation Front; Linda Faith Greene (AKA Lindy Greene); Hillary Roney; Kevin Olliff; Ramin Saber; Tim Rusmisel and DOES 1-100, inclusive. http://www.newsroom.ucla.edu/portal/ucla/ document/Regents_Complaint.PDF.

University of California (2009) http://www. newsroom.ucla.edu/portal/ucla/extremistsrepeatedly-target-ucla-87202.aspx.

Wikipedia (2009) The Great ApeProject.http://en. wikipedia.org/wiki/Great_Ape_Project. 